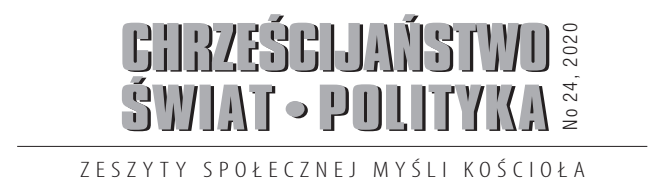

Bianka Speidl

Pázmány Péter Catholic University, Hungary

ORCID: 0000-0001-6140-594X

\title{
Overview of the conference "Secularism as a challenge for politics and political science",
}

\section{Warsaw 12-13 December 2019}

The second biannual conference on religion and politics focusing on secularism as a challenge for politics and political science proved above all, that defining the cope and role of religion in a secular and post-secular context does not mean exclusive confinement to empirical or positivistic rationality. Rather, openness to include moral and spiritual/religious truth, brings depth to our reflection and indispensable for a novel and realistic approach. Keynotes speakers prof. Joseph Weiler and prof. Fabio Petito as well as all panelist made important contributions to outline a much-needed new paradigm. Fabio Petito in his opening speech pointed out that in international relations and political science we are in "post-secular" moment, in which we search for new paradigm, as the secular one is no longer convincing.

Prof. Weiler raised attention to the fact that Europe's political culture is rooted in two sources, the Greek and Christian traditions and the Christian foundation of our modem tradition of Human Rights considered as a major secular achievement, is undeniable. The constitutional pluralism of Europe is the fruit of tensions and syntheses of these two traditions, and it is impossible to understand political culture-even secular political culture, the most secular intellectual and political trends and states without considering this legacy. In addition, this means freedom to determine the scope of religion in the collective and public space with respect to the history of the given country, the nature of its religious traditions and communities, and pragmatic considerations of how best the state may ensure peaceful coexistence among religious factions. 
Another important and re-emerging observation was that the blurring of the boundaries between the various religions, religious traditions and religious regulations leads to pitfalls. In civilisations inspired by Christianity, the Sacred and the Profane are linked but enacted in separate spheres or dimensions. The outward manifestation of religion belongs to the realm of sacred with its earthly manifestations, while the profane everyday life can be evaporated and fertilised by values rooted in religion but not its outward manifestations. Worship and daily life are complementary but not conflated.

Summarising and highlighting the discussions conducted in thirteen panels and over seventy lectures is a very difficult task. As a participant observer I felt the best way to convey the breadth and length of the discussions is to include all the contributions in a brief and concise manner assorted in thematic paragraphs each encompassing one or more panels.

The theoretical framework regarding the definition, the modalities the dangers and the opportunities of secularism was widely studied. Prof. Dariusz Góra raised attention to the thesis of Harvey Cox, initiator of one of the most vivid contemporary debates on secularization and secularism, who considered secularism as an opportunity to develop a fresh type of Christian commitment. Tamás Nyirkos analysed whether we can call modern political ideologies as the secular analogues of religious belief systems or will only help them to distinguish themselves as more "objective", "realistic", or "scientific" than traditional belief systems, which is very probably not the case. In the context of post-secularism, Tomasz Szymański presented the religious and political concepts of two French representatives of 19th-century lay humanitarianism, Pierre Leroux and Edgar Quinet. Przemysław Piotrowski analysed a post-secular turn in the concept of the history of British democracy represented by Maurice Cowling's reflection on the political crisis in the United Kingdom in 1920-1924.

With regards to the religious elements in secular societies, Prof. John Madeley examined the empirical limits of state secularity and religiosity as variously understood and placed a large question-mark against still-prevailing assumptions about the secularity of the European state further eroded by the recent emergence within Europe of communities representing other world religions for which the secular-religious conceptual dyad has no, little, or very different, resonance. Lucyna Chmielewska presented the biblically sanctioned concept of The Covenant as a possible religious sources of secularism as it carried a universal 
content (prohibition of killing, protection of life, responsibility of the people before the people, justice) that proved to be indispensable in the construction of a secular state. Paweł Milcarek argued that secularism as a postulate of political hedonism that aims to protect the citizens' freedom from fear does not require the complete removal of religion from public space, rather it is a motive for vesting religion with "friendlier" characters that does not confront with hedonistic consensus.

In exploring the dilemmas of Post-Secularism, Rev. Karol Jasiński analysed the character of contemporary, new forms of spirituality and deinstitutionalisation which, on the one hand, is marked by secularization and secularism, on the other, it is the result de-secularization and post-secularism, claiming that post-secularism does not mean the return of the old religious order, but rather the opening of other perspectives and the search for a new spiritual experience. In a similar vein, Prof. Stanisław Obirek offered a positive assessment of post-secularism as an attractive alternative to the theory of secularization. As for overcoming the apparent confrontation between Christianity and Western rationalism, he recalled the innovative meeting of Jürgen Habermas with Joseph Ratzinger in 2004. Prof. Wojciech Gizicki scrutinised whether the world will be more secure under the "rule" of the so called "secular religions".

The ideas of Benedict XVI on the corrective role of religion in relation to reason constituted subjects of two other talks as well. Rev. prof. Janusz Węgrzecki studying the relationship between ethics and reason highlighted the ideas of Benedict XVI noting that great religious traditions are guardians and promoters of ethical values without which reason cannot work properly, nor can a policy of a democratic state of law be properly conducted. Rev. prof. Wiesław Łużyński scrutinised the concept of "Healthy secularity» proposed by Benedict XVI regarding the relations between the Church and the state built on the conviction that the church does not identify with any political system, party or state and respects the autonomy of earthly realities, while the state belongs to the sphere of profane. The creative presence of the Church in the public sphere of life means that it is the guardian of the ethical foundations of the state and law, can freely conduct educational and charity activities as well as indirectly engage in building a more just society.

On the issue of political theology and the political science of religion, Prof. Adam Wielomski critically examined the currently fashionable term "political theology". Robert Pawlik juxtaposed Carl Schmitt's thesis that all the main concepts of 
modern science of the state are secularized theological concepts, by transferring the religious to the secular sphere with the concept of Ernst H. Kantorowicz, whose approach to the genesis of state institutions highlighted a processes of "sanctification". Arkadiusz Górnisiewicz investigated secularization as one of the key elements in the development of modern international law and a turn towards the undifferentiated concept of war reflecting on the ideas of Carl Schmitt and Hanno Kesting's thesis of criminalizing the enemy. The ideas of Eric Voegelin were studied in two talks: Marek Popielarski shed light on the importance of secularism by Thomas Hobbes as understood by Voegelin, while Agnieszka Tarnowska scrutinised Voegelin's conceptualisation of modern political religions and secularized gnosis. Waldemar Rogowski reviewed the reasons for secularization in the views of the Priesthood of Pius X.

Prof. Leszek Graniszewski assessed the role of identity policy in the modern world, its impact on international relations between states and societies belonging to different civilization circles of the modern world.

Secularism as a social phenomenon and challenge for political science was another crucial topic explored. Prof. Maria Marczewska-Rytko pointed out the main challenges that researchers face the phenomenon of secularism in political science. Prof. Sławomir Sowiński talked about the prospects of reducing tension between religion and politics in political science and the pitfalls of simplistic solutions. Prof. Łukasz Młyńczyk raised the question whether the approach of cognitive secularism in political sciences enable it to meet the standards of scientific objectivism. Furthermore, he investigated the consequences of qualifying the political science of religion as social science and religions as cultural sciences. Rev. Remigiusz Szauer investigated the understanding of public morality based on theoretical considerations and empirical research Anna Solarz emphasised that in order to assess the religious factor there is a need to revise secularism as part and parcel of the way of thinking about international reality and redefine its place and importance, adding that post-secularism may offer a solution by stimulating a new approach towards religion. Tadeusz Szawiel examined the problematic of the dilemma between reason and revelation in light of the writings of Leo Strauss and Max Weber. Prof. Paweł Kaczorowski scrutinised the consequences of perceiving reality through the lenses of secularization. Agnieszka Bógdał-Brzezińska investigated the impact of digital technologies as a tool for secularization of societies that shape individual and social awareness as well as influence the scale and level of religiosity. 
Another genre of talks presented case studies of church-state relations, bringing examples from far and near. Covering Western Europe and the Mediterranean, Prof. Remigiusz Forycki analysed the French model with special attention to scientific theories of secularization and post-secularization as well as specific actions aimed at eliminating Catholicism in France. Beata Springer highlighted aspects of Bavarian religiosity - understood as attachment to tradition, cultivating and protecting its identity - that tend to collide with the mainstream secularization trends in Western Europe, which however is undergoing profound changes and a separation from religious practices and church institutions. The peculiarities of the Maltese situation were discussed in two talks. Adam Liwak described Malta as an example of semi-secularization, a consequence of the political system developed under the Order of St. John, which continues to affect the social, political and religious reality as well as shaped by the successive Maltese political systems. Prof. Sylwia Góra discussed the constitutional regulation in Malta that combines elements typical of a classical confessional state with elements specific to a secular state. Wioletta Husar-Poliszuk explored and explained the phenomenon of Catalan independentism in the context of the new secular religion in the region.

Countries with orthodox majority were dealt with in a couple of panels from various perspectives. Prof. Stefan Dudra's talk was dedicated to the social teaching of two autocephalous Orthodox churches, the Russian Orthodox Church and the Romanian Orthodox Church which published comprehensive documents related to social and bioethical issues in particular. Agata Domachowska provided an insight into the role of the state in the conflict between the Serbian Orthodox Church and the Montenegrin Orthodox Church in Montenegro. Renata Król-Mazur analysed the role religion plays in contemporary Georgia, the efforts by the Orthodox Autocephalous Apostolic Church of Georgia to regain its place in public space, and how the state-church relations in that country were regulated legally with special attention to the place of religion in public education. Roman Romantsov examined the controversies that followed the creation of the Orthodox Church of Ukraine in December 2018, which according to the current Ukrainian authorities is conducive to the consolidation of Ukrainian society while a large number of parishes and religious sites stay subordinated to the Ukrainian Orthodox Church of the Moscow Patriarchate. Juliia Kornichuk examined the current state of church-state relations in Ukraine in the context of the process of gaining Autocephaly by the Orthodox Church of Ukraine and identified its impact on religious life in Ukraine, on state policies in the religious sphere and on the understanding of the rights to religious freedom. Rev. 
prof. Marcin Składanowski explored the mystical-religious content of President Putin's political discourse highlighting the gap between the proclaimed appreciation of the religious sphere in political life and the actual undertaking of radical value-based transformations. Marcin Pisarski analysed the impact of Corneliu Zelea Codreanu a radical nationalist activist, leader of the Iron Guard the interwar period, perceived by his followers as an Orthodox religious mystic on the thoughts of modern nationalist groups in Romania.

As far as Central and Eastern Europe is concerned, Dominik Héjj analysed Christianity as a tool in building the image of the state in Hungary and in conducting and legitimizing specific political activities, while Prof. Piotr Bajda investigated Czechia the most secularized state of the Visegrad Group, the genesis of its current de-Christianization and secularization as well as the contemporary situation of the Catholic Church in the Czech Republic. Prof. Tadeusz Kamiński compared the conditions of church charity activities in Poland, Czechia and Hungary, concluding that the importance of church charitable organizations depends neither on the degree of religiosity of the studied societies nor on the size and political position of a given Churches, rather on the specific political heritage and social reality of the studied countries. Inese Runce analysed the interplay between democratic and Soviet attitudes in regulating the life and activities of religious denominations in Latvia after 1991. Joanna Kulska provided an overview of the place and the importance of the religious factor in the selected countries of Central and Eastern Europe three decades after the transformation in 1989, concluding that the region represents significant diversity in the area of political culture and institutionalized politics.

On exploring Church - State Relations and politics in Poland, Prof. Małgorzata Swider analysed the humanistic vision of politics proposed in a speech by pope St. John Paul II, delivered in 1999 in the Polish Parliament, a memorable textual source of participatory politics. Rev. Rafał Leśniczak assessed the degree of presence of the idea of secularism in the election programs of the main political parties running in the 2019 Polish parliamentary elections. Robert Zapart outlined the possibility and limits of cooperation between the Catholic Church and military, social, ecological institutions. Rev. prof. Janusz Balicki studied the process of secularization in Europe as it appears in the right-wing political discourse in Poland. Piotr Pochyly analysed the secular attitudes and tendencies in the work of the Foreign Affairs Committee of the Sejm of the Republic of Poland under the various administrations between 2001 and 2019. Laura Orawski studied the 
use of Catholicism as a tool of identity construction by Poland's Law and Justice Party since 2015.

Regions outside Europe were covered in a wide range of talks. Prof. Rafał Prostak analysed the criticism elaborated by H.R. Niebuhr and Russell D. Moore regarding the evangelical concept of American society as a "Christian nation" dating back to the Puritan colonization of New England and widely promoted by the contemporary Religious Right. Marta Osuchowska in her presentation described the complex and strong relationship between religion and law in Latin America, a consequence of the fact that in order to cover the largest possible area of evangelization, the Church practically gave its own autonomous rule to civil authorities. A situation that bears a significant impact on the religious diversity of the societies and created cleavages between the proponents of national liberation who were Catholics, often educated at religious universities and the top clergy, most of whom were in opposition to the movements of independence. Marcin Szydzisz in his talk about the State of Israel highlighted that citizens committed to secularism have a clear "non-religious identity." Consequently, the tension between religious, usually ultra-orthodox, groups and the liberal milieu of secular Jews is the most serious division axis in Israeli society. Paulina Napierała analysed the varied attitudes and apprehensions of African American churches - that is Protestant churches that minister to predominantly Black congregations - to the Charitable Choice solutions of 1996 that aims to bring religion back into the American welfare system. Ankur Yadav analysed how right-wing populism in India stimulated a shift in the idea of secularism from 'Pseudo-Secularism to Mono-Secularism'. Heewon Kim demonstrated the anomalies of equal opportunity policies for religious minorities in India from the perspective of morality policy. Jarosław Tomasiewicz studied the various models of nationalism with special attention to the National Volunteer Association (RSS) which has become the most dynamic advocate of Hindutva ideology. Rev. Tadeusz Jarosz scrutinised the concept of secularism as a condition for the consolidation of relations between politics and religion in Tanzania.

The religious aspects of European integration were explored from multiple perspectives. Rosita Garškaite offered an interpretative approach that highlights a constitutive rather than causal relationship between religious denomination and support for the EU integration. Anita Budziszewska highlighted the foundations of the emerging new right to culture in the pronouncements of the Council of Europe and in the rulings taken by European Court of Human Rights that show a tendency towards prioritizing the right to culture over right to religious practice, 
and the need for striking a balance between them. Pablo de la Fuente de Pablo raised attention to new patterns of religious intolerance in Spain primarily targeting Catholic symbols. Irena Rysińska studied the impact of religious divisions on the integration process in Europe. Jerzy Ciechański highlighted that the Catholic Church ever uses its right to vote in the Council of Europe despite the fact that it has good reasons, and solid arguments to argue with the CE's vision of "progress" that considers human rights as an effective instrument for normalizing an ever-expanding catalogue of values as well as their plastic interpretation.

With regards to the political relevance and impact of Islam, Anna Zasun addressed the range of Islam's political nature as to what extent the specificity of the religion itself and to what external contexts determine the political dimension of Islam. Prof. Ryszard Michalak analysed the strategies of desecularization and re-Islamization as determinants of the policy of Recep Tayyip Erdoğan and indicated the reasons and manifestations of the increase in the importance of the religious factor in contemporary Turkish politics. Piotr Ślusarczyk investigated the reasons behind the failure of the idea of European Islam, rooted in the Islamic doctrine as well as the sluggish process of secularisation of the Islamic community in Europe. Wiesław Lizak studied the scope of Muslim fundamentalism in West Africa and its impact for the security of the region. Marcin Rzepka provided a multifaceted analysis of the activities of Iranian institutions responsible for promoting religion (Shiism) with the aim of creating "global Shiism" based on regional and supra-regional links and networks. Paulina Warsza analysed the relation between national and religious identity in Iraqi Shiism as well as the role of Najaf in the national resistance. Mariusz Sulkowski compared Sajjid Qutb's concept of the two realms that of the divine and the worldly that should be connected with the spiritual approach of Saint Augustine. Bianka Speidl investigated the importance of the concept of (religious) authority in the process of integration in Europe's Muslim communities. 